\title{
Self-Organization Features of Tetraphenylporphyrins according to Quantum Chemical Calculations
}

\author{
M. A. Elistratova, ${ }^{a}{ }^{@}$ I. B. Zakharova, ${ }^{\text {b }}$ and O. E. Kvyatkovskii ${ }^{a}$ \\ aIffe Institute, Russian Academy of Sciences, 194021 St. Petersburg, Russia \\ ${ }^{\mathrm{b}}$ Peter the Great St. Petersburg Polytechnic University, 195251 St. Petersburg, Russia \\ ${ }^{\circledR}$ Corresponding author E-mail: marina.elistratova@mail.ioffe.ru
}

\begin{abstract}
The optimal geometry of molecules of tetraphenylporphyrin $\left(\mathrm{H}_{2} \mathrm{TPP}\right)$, its zinc complex (ZnTPP) and their dimers and trimers, as well as the HOMO-LUMO energy gap and the binding energies of the complexes, and some other parameters were calculated by quantum chemical method. The calculations of the electronic structure of (MeTPP) complexes were carried out in the framework of the density functional theory with the B3LYP hybrid functional using MOLCAO SCF with atomic sets of basic Gaussian functions 6-311G (2df, 2pd) with polarizing $d$ and ffunctions. The difference in energy gain during the formation of dimers and trimers gave an explanation of the self-organization features of different types of porphyrins. The connection between configurations of the basic states of trimers and self-organization properties of selected materials is presented. An explanation of the relationship between the type of porphyrin and its self-organization properties is given. The ground states of the ZnTPP and $\mathrm{H}_{2}$ TPP trimers have different geometry configuration - "Zig-zag" for ZnTPP and "Stairs" for H,TPP. Due to this fact these materials have different ability to form linear self-organized structures. The energy gain during the formation of the ZnTPP trimer with the optimal configuration is $13.23 \mathrm{kcal} / \mathrm{mol}$, and for $\mathrm{H}_{2} T P P$ is $7.79 \mathrm{kcal} / \mathrm{mol}$. It was concluded that ZnTPP is not prone to self-organization into linear structures under normal crystallization conditions. Whereas the ground state of (ZnTPP) ${ }_{3}$ has a "Zig-zag" geometry, it tends to form planar structures. The large difference between ground and minor states makes it difficult to control self-organization and the growth of nanostructures. The ground state in the geometry of the "Stairs" and the small energy difference between other $\left(\mathrm{H}_{2} \mathrm{TPP}\right)_{3}$ configurations, on the contrary, allows growing various modifications of structures, including nanowires, with simple technological changes.
\end{abstract}

Keywords: Self-organization, tetraphenylporphyrin, dimers, trimers, quantum chemical calculations, nanowires.

\section{Особенности самоорганизации тетрафенилпорфиринов по данным квантово-химических расчётов}

\author{
М. А. Елистратова, ${ }^{\text {a }}$ И. Б. Захарова, ${ }^{\text {b }}$ О. Е. Квятковский ${ }^{\mathrm{a}}$ \\ ${ }^{\mathrm{a}}$ Физико-технический институт им. А.Ф. Иоффе Российской академии наук, 194021 Санкт Петербург, Россия \\ ${ }^{\mathrm{b}}$ ФГОУ ВО «Санкт-Петербургский политехнический университет Петра Великого», 195251 Санкт Петербург, \\ Россия \\ ${ }^{\circledR}$ E-mail: marina.elistratova@mail.ioffe.ru
}

\begin{abstract}
В работе представлень результаты квантово-химических расчетов оптимальной геометрии молекул тетрафенилпорфирина (Н,TPP) и его Zn(II) комплекса (ZnTPP), их димеров и тримеров, энергетической щзели ВЗМО-НВМО и энергий связи комплексов, а также другие параметры. Показана связь конфигураций основных состояний тримеров со свойствами самоорганизаџии выбранных материалов. Дано объяснение связи типа порфирина со свойствами самоорганизации. Основное состояние тримера (ZnTPP), имеет конфигурацию «зигзаг», а $\left(\mathrm{H}_{2} \mathrm{TPP}\right)_{3}$ - «лестнищь»». Выцгрыш в энергии при образовании тримера оптимальной конфигурации для ZnTPP составляет 13.23 ккал/моль, а для Н,ТРP-7.79ккал/моль. Сделан вывод, что тетрафенилпорфиринат иинка не склонен к самоорганизации в линейные структуры при обычных условиях кристаллизации, поскольку его основное состояние имеет геометрию «зигзаг», не способствуюшую росту линейных структур.
\end{abstract}


Большая разница энергии связи основного и других состояний тримера (ZnTPP) затрудняет возможность контролировать самоорганизацию и рост линейных структур. Основное состояние в геометрии «лестница» и небольшая разница энергий между другими конфигурациями (H,TPР), напротив, позволяют выращивать различные модификации структур, в том числе нанонити, при несложных технологических изменениях.

Ключевые слова: Самоорганизация, тетрафенилпорфирин, димеры, тримеры, квантово-химические расчёты, нанонити.

\section{Introduction}

Porphyrins are a class of organic materials derived from porphin, which is a planar macrocycle formed by four pyrrole rings connected by methine bridges. A bivalent metal atom can be placed in the center of the tetrapyrrole macrocycle instead of two hydrogen atoms, forming various metalloporphyrins. All porphyrins are organic semiconductors with strong absorption in the ultraviolet and visible spectral regions; some of them exhibit intensive fluorescence. Functional materials from the porphyrin group are of great interest in various fields of nanotechnology as a component of solar cells, ${ }^{[1]}$ organic light-emitting devices, ${ }^{[2]}$ etc. Single molecules and two-dimensional structures based on tetraphenylporphyrin are quite actively studied, ${ }^{[3]}$ including theoretically. However, three-dimensional self-organization of porphyrins has not been enough studied. Organic nanocomposite structures attract more and more attention of researchers for creating optoelectronic devices. ${ }^{[4,5]}$ One of the promising approaches to create nanostructures are methods that use the self-organization of organic semiconductors - the process of ordering molecules due to internal factors, without an external specific effect or using a stimulating impact. The fundamental difference from standard methods is that the desired structure is created "from scratch" and the minimum possible size is comparable with the size of the molecules (tens of angstroms). Standard semiconductor technology (CMOS) occurs from bulk material and requires many stages (etching, lithography, etc.), which significantly increases the size and cost of manufactured product.

Solid-state films from the group of porphyrins obtained both by liquid and thermal evaporation methods exhibit an ability of self-organization, which makes it possible to obtain various structures and control their growth by changing technological parameters. Self-organized nanowires, nanorods, and other linear structures from porphyrins may be obtained as a result, which can be used in optoelectronic devices for various purposes. ${ }^{[6]}$

Numerous works have experimentally shown the phenomena of both two-dimensional ${ }^{[7]}$ and three-dimensional ${ }^{[8]}$ self-organization of porphyrin molecules during condensation on various substrates. However, the reasons of this behavior have not been studied in detail. Earlier, we showed that the phenomenon of self-organization can manifest itself in different ways depending on external factors introduced by the experimenter (production method, type of substrate, etc.). ${ }^{[9]}$ At the same time, the growth of linear self-organized structures is difficult for some others porphyrins (ZnTPP $\left.{ }^{[6]}\right)$ made by any production methods. The goal of this work was to explain the self-organization properties of some teraphenylporphyrins using quantum chemical calculations.

\section{Methods of Quantum Chemical Calculations}

Two porphyrins were chosen as materials for study: tetraphenylporphyrin $\mathrm{H}_{2}$ TPP, in which four phenyl groups located at 5,10,15,20-positions, and zinc tetraphenylporphyrin ZnTPP, which has a $\mathrm{Zn}^{2+}$ in the center of the porphyrin macrocycle instead of two hydrogen. The goal of theoretical study was: 1) the choice of several symmetric configurations (MeTPP) ${ }_{n}$ of complexes where $n=2,3$ $\left(M e=\mathrm{H}_{2}\right.$ or $\mathrm{Zn}$ ), suitable from general considerations for the formation of stable complexes; 2) complexes geometry configuration; 3) calculations of complexes electronic structure with optimized geometry, including calculations of total energy $E_{\text {tot }}$, complexe formation energy $E_{\text {form }}=n E_{\text {tot }}(M e \mathrm{TPP})-E\left[(M e T P P)_{n}\right]$, and finding the HOMO-LUMO gap in the single-electron spectrum. To solve this problem, we performed quantum chemical calculations of the electronic structure of complexes (MeTPP) in the framework of the density functional theory with the hybrid functional B3LYP ${ }^{[10-12]}$ by the MOLCAO SCF method from the GAUSSIAN03 software package ${ }^{[13]}$ with atomic sets of basic Gaussian functions 6-311G (2df, 2pd) with polarizing $d$ and $f$ functions. Calculations showed that all considered configurations are stable. Optimal configurations were found with a minimum total energy for all complexes, which for brevity we call the ground state energy of this complex and denote it by $E_{\mathrm{GS}}$. A detailed description of the calculation results can be found in Tables $1-4$ and in the following sections of the present work.

\section{Results and Discussion}

A specific feature of tetraphenylporphyrin molecules structure is that the macrocyclic backbone of tetraphenylporphyrin has a planar structure, while the four phenyl groups are perpendicular to the plane of the tetrapyrrole macrocycle. The optimized geometry of the $\mathrm{H}_{2}$ TPP and ZnTPP molecules is shown in Figure 1a,b according to calculations. It is seen that nitrogen atoms form a square in the center of the molecule. Inside the $\mathrm{N}_{4}$ square, metal atoms with a $2^{+}$valency (Figure 1a) or two hydrogen atoms (Figure 1b) can be located. The $\mathrm{Zn}$ atom located in the center of the macrocycle, and the ZnTPP molecule has $\mathrm{D}_{4 \mathrm{~h}}$ symmetry. Two hydrogen atoms in the $\mathrm{H}_{2}$ TPP molecule are located along one of the axes and symmetrically with respect to the center, which results in the $\mathrm{D}_{2 \mathrm{~h}}$ symmetry of $\mathrm{H}_{2} \mathrm{TPP}$.

Quantum chemical calculations of the optimal geometry, total energy, formation energy, and electronic structure were performed to explain the possible causes of some porphyrins self-organization into linear structures (nanowires and nanorods) and the absence such effect of others. The crystal structures constructing model was based on dimers and trimers (complexes of two and three porphyrin molecules, respectively) $\mathrm{H}_{2}$ TPP and ZnTPP. Data for various possible geometry of dimers and trimers were obtained, and given in the tables of present paper. 

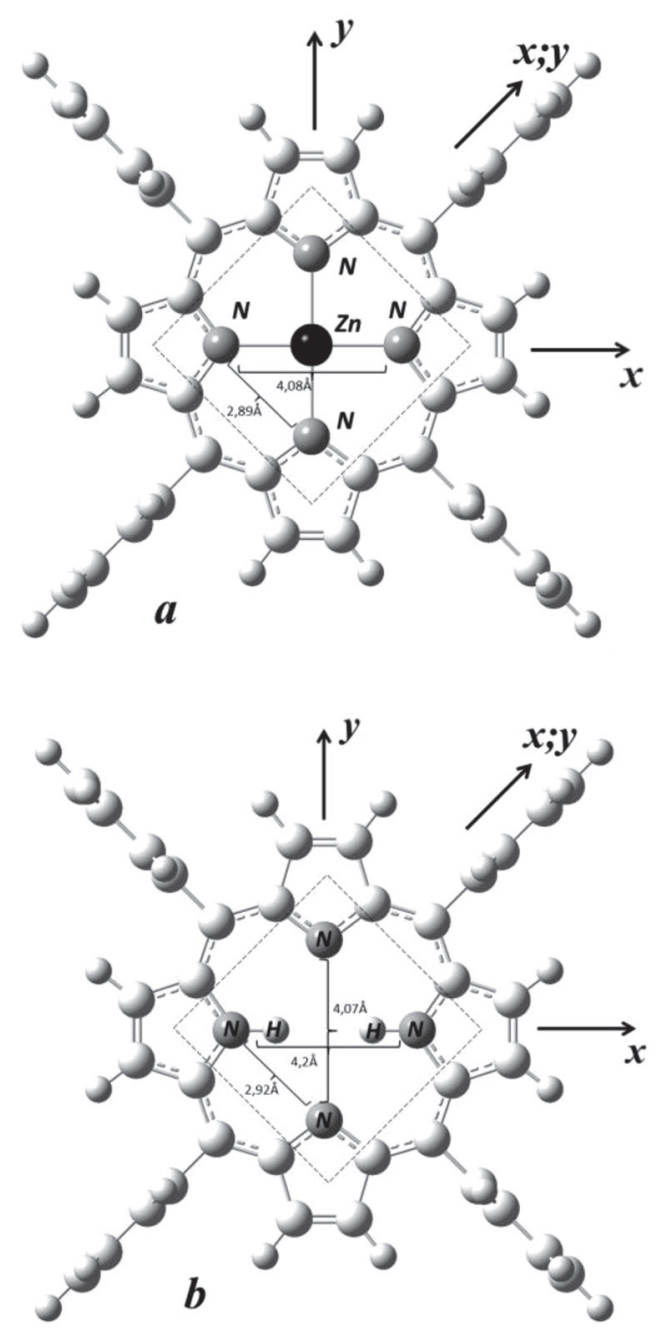

Figure 1. Optimal geometries of $\operatorname{ZnTPP}(a)$ and $\mathrm{H}_{2} \mathrm{TPP}(b)$ molecules according to quantum chemical calculations. The directions $x$ and $y$ are shown, the diagonal $x ; y$ is located in the phenyl rings direction.

The following designation was introduced to describe the geometry of structures. The direction of $x$ and $y$ axes relative to the tetrapyrrole macrocycle is introduced in Figure 1. The possible displacement of the upper molecule relative to the lower can be both in the $x$ and $y$ axes directions, and diagonally in the direction $x ; y$, i.e., in the direction of the phenyl rings. A configuration is also considered where one molecule is located above another with a rotation of $45^{\circ}$ and without displacement. A general view of the construction of such structures is shown schematically in Figure 2, where the square indicates the tetrapyrrole macrocycle.

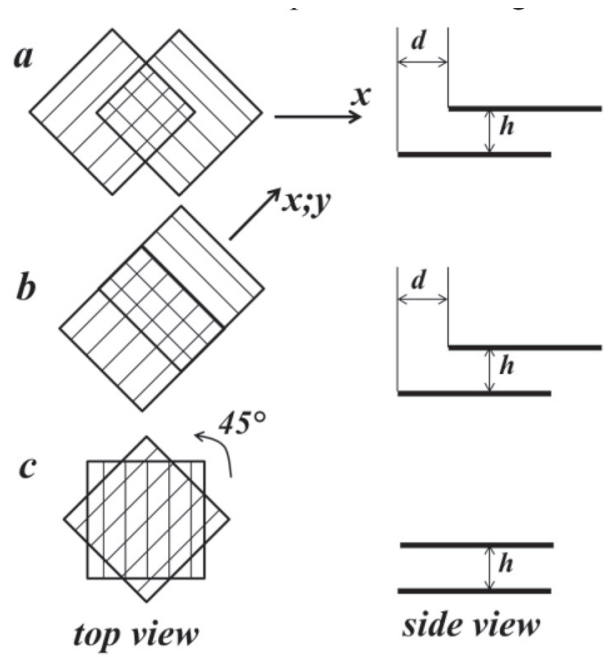

Figure 2. The main configurations for dimers constructing. Top view (left) and side (right) are shown.

It was found that the minimum total energy of the complexes and, accordingly, the optimal geometry, is achieved when the porphyrin molecules shift relative to each other according to the calculation results. Distances between the planes of molecules $h$ and the displacement $d$ calculated by the lateral distance between the centers of the macrocycles (see Figure 2) were determined. The calculations showed that the distance between the planes of the molecules $h$ decreases in a number of different calculated geometries of complexes when approaching the optimal configuration. The distance between the planes of molecules for the ground state of the dimer and trimer $\mathrm{H}_{2}$ TPP is $4.7 \AA$, and the next for the minor energy is $5.3 \AA$. For ZnTPP, the value of $h$ is $4.7 \AA$ for the ground state, and $5.2 \AA$ for the minor.

The calculations for the dimer (ZnTPP), showed (Table 1) that the ground state with the lowest total energy is such that the second molecule moves diagonally relatively the first, towards the phenyl groups (see Figure 2b). The energy gain in the formation of a dimer of optimal geometry is $7.91 \mathrm{kcal} / \mathrm{mol}$ (i.e., $3.94 \mathrm{kcal} / \mathrm{mol}$ per ZnTPP molecule), which is much more than in the other considered geometry variations. One molecule is located above another configurations without displacement with a rotation of $45^{\circ}$ has an energy much higher than the energy of the ground state.

The calculations for $\left(\mathrm{H}_{2} \mathrm{TPP}\right)_{2}$ dimers are presented in Table 2 and are generally similar to the results for (ZnTPP $)_{2}$. During the formation of $\left(\mathrm{H}_{2} \mathrm{TPP}\right)_{2}$ dimers, shifting in the $x$ and $y$ directions become nonequivalent due to a symmetry decrease. However, the optimal geometry is also

Table 1. Optimized geometry and electronic properties calculation results for $(\mathrm{ZnTPP})_{2}$ dimers.

\begin{tabular}{lcccc}
\hline \multicolumn{1}{c}{ Type and symmetry of dimers } & \multirow{2}{*}{$E_{\mathrm{tot}}$, a.u. } & $\begin{array}{c}E_{\mathrm{tot}}-E_{\mathrm{GS}}, \\
\mathrm{kcal} / \mathrm{mol}\end{array}$ & $\begin{array}{r}\left.2 E(\mathrm{ZnTPP})-E_{\mathrm{tot}}[\mathrm{ZnTPP})_{2}\right], \\
\mathrm{kcal} / \mathrm{mol}\end{array}$ & $\begin{array}{c}\text { HOMO-LUMO, } \\
\mathrm{eV}\end{array}$ \\
\hline Shifting towards $x ; y$, towards phenyl group, $C_{2 \mathrm{~h}}\left({ }^{1} A_{\mathrm{g}}\right)$ & -7385.078054 & 0 & 7.91 & 2.847 \\
Shifting towards $x$, between phenyl groups, $\left.C_{2 \mathrm{~h}}{ }^{1} A_{\mathrm{g}}\right)$ & -7385.071315 & 4.21 & 3.67 & 2.788 \\
Rotation on $45^{\circ}$ without shifting, $D_{4 \mathrm{~d}}\left({ }^{1} A_{1}\right)$ & -7385.070470 & 4.75 & 3.14 & 2.825 \\
\hline
\end{tabular}

*a.u. $=27.212 \mathrm{eV}$ is the atomic unit of energy 
Table 2. Optimized geometry and electronic properties calculation results for $\left(\mathrm{H}_{2} \mathrm{TPP}\right)_{2}$ dimer.

\begin{tabular}{|c|c|c|c|c|}
\hline Type and symmetry of dimers & $E_{\text {tot }}$, a.u. & $\begin{array}{l}E_{\mathrm{tot}}-E_{\mathrm{GS}} \\
\mathrm{kcal} / \mathrm{mol}\end{array}$ & $\begin{array}{c}2 E(\mathrm{ZnTPP})-E_{\mathrm{tot}}\left[(\mathrm{ZnTPP})_{2}\right] \\
\mathrm{kcal} / \mathrm{mol}\end{array}$ & $\begin{array}{c}\text { HOMO-LUMO, } \\
\text { eV }\end{array}$ \\
\hline Shifting towards $x ; y$, towards phenyl group, $C_{2 \mathrm{~h}}\left({ }^{1} A_{\mathrm{g}}\right)$ & -3828.65954 & 0 & 3.94 & 2.738 \\
\hline Shifting towards $x$, between phenyl groups, $C_{2 \mathrm{~h}}\left({ }^{1} A_{\mathrm{g}}\right)$ & -3828.65892 & 0.37 & 3.57 & 2.714 \\
\hline Rotation on $45^{\circ}$ without shifting, $D_{2}\left({ }^{1} A\right)$ & -3828.65720 & 1.48 & 2.49 & 2.675 \\
\hline
\end{tabular}

when the second molecule shifts in the $x ; y$ direction toward the phenyl groups. In this case, the energy gain of the dimer formation is $3.94 \mathrm{kcal} / \mathrm{mol}$ (i.e., $1.96 \mathrm{kcal} / \mathrm{mol}$ per one $\mathrm{H}_{2} \mathrm{TPP}$ molecule), which is smaller than $E_{\text {form }}\left((\mathrm{ZnTPP})_{2}\right)$. The difference in the dimer formation energies of the ground state and the closest configuration (by energy) is not very large and amounts $0.37 \mathrm{kcal} / \mathrm{mol}$. The HOMO-LUMO energy gap decreases with the dimers formation, compared with a single molecule (see Table 2).

The number of possible scenario of molecules selforganization increases with an increase of molecules number organizing the structure. Keeping in mind different directions of molecules displacements, possible configurations can be divided into three groups. A "Straight stair" is a scenario in which each subsequent molecule shifts in the same direction as the previous one. A "Back step stair" - each subsequent molecule shifts in the direction opposite to the previous one. A "Zig-zag" structure - molecules shift in a spiral after the initially chosen direction. In all cases, the shifts value is constant modulo.

Optimization of the geometry and the total energy of the trimer were calculated. The ground state of (ZnTPP) ${ }_{3}$ (i.e., the state with the lowest energy) is such that the second molecule shifts in the $x ; y$ direction in relation to the first one, and the third shifts towards $-x ; y$ in a relation to the sec- ond, and rotates $90^{\circ}$ from the original offset, i.e., "Zig-zag" structure is formed (see Figure 3a).

The energy gain of the (ZnTPP) 3 trimer formation of is $13.23 \mathrm{kcal} / \mathrm{mol}(4.4 \mathrm{kcal} / \mathrm{mol}$ per molecule), which is bigger than for dimers. An increase of the formation energy gain with an increase of molecules number contributes to further self-organization of the structure. It is easy to continue the molecular series and assume that in such a ground state the growth of planar structures is most likely. The shifting of the third molecule in the same direction as the second is non-optimal - this geometry of the complex is $2 \mathrm{kcal} / \mathrm{mol}$ higher in energy. The formation of nanowires (nanorods) is most likely for "Stairs" geometries, that is for ZnTPP this behavior will not be typically.

The calculations of the total energy, the energy of complexes formation and the differences between the energies of formation for various shifting scenarios for $\left(\mathrm{H}_{2} \mathrm{TPP}\right)_{3}$ trimers are shown in Table 4. Unlike the (ZnTPP) 3 trimer, the ground state here is the "Straight stair" (Figure 3b). The difference between the ground state with the lowest total energy ("Straight stair") and the first minor state ("Zig-zag") is $14 \mathrm{meV}$, between the ground and second minor state ("Back step stair") $-24 \mathrm{meV}$. The energy gain of the trimer formation from three single $\mathrm{H}_{2}$ TPP molecules is $7.79 \mathrm{kcal} / \mathrm{mol}$ (i.e., $2.6 \mathrm{kcal} / \mathrm{mol}$ per molecule). Note that, the energy gain

Table 3. Optimized geometry and electronic properties calculation results for (ZnTPP) $)_{3}$ trimers.

\begin{tabular}{|c|c|c|c|c|}
\hline Type and symmetry of trimers & $E_{\text {tot }}$, a.u. & $\begin{array}{l}E_{\mathrm{tot}}-E_{\mathrm{GS}} \\
\mathrm{kcal} / \mathrm{mol}\end{array}$ & $\begin{array}{c}2 E(\mathrm{ZnTPP})-E_{\mathrm{tot}}\left[-(\mathrm{ZnTPP})_{2}\right] \\
\mathrm{kcal} / \mathrm{mol}\end{array}$ & $\begin{array}{c}\text { HOMO-LUMO, } \\
\text { eV }\end{array}$ \\
\hline "Zig-zag" structure with shifting towards $x ; y$ or $-x ; y, \mathrm{C}_{2}\left({ }^{1} \mathrm{~A}\right)$ & -11077.61930 & 0 & 13.23 & 2.807 \\
\hline "Straight stair" with shifting towards $x ; y, \mathrm{C}_{2 \mathrm{~h}}\left({ }^{1} \mathrm{~A}_{\mathrm{g}}\right)$ & -11077.61720 & 1.31 & 11.92 & 2.821 \\
\hline "Back step stair" with shifting towards $x ; y, \mathrm{C}_{2 \mathrm{v}}\left({ }^{1} \mathrm{~A}_{1}\right)$ & -11077.61513 & 2.63 & 10.60 & 2.862 \\
\hline "Zig-zag" structure with shifting towards $x$ or $y, \mathrm{C}_{2}\left({ }^{1} \mathrm{~A}\right)$ & -11077.60849 & 6.78 & 7.12 & 2.764 \\
\hline "Straight stair" with shifting towards $x, \mathrm{C}_{2 \mathrm{~h}}\left({ }^{1} \mathrm{~A}_{\mathrm{g}}\right)$ & -11077.60849 & 6.78 & 6.45 & 2.765 \\
\hline "Back step stair" with shifting towards $x, \mathrm{C}_{2 \mathrm{v}}\left({ }^{1} \mathrm{~A}_{1}\right)$ & -11077.60815 & 6.98 & 6.25 & 2.784 \\
\hline Serial rotation on $45^{\circ}$ without shifting, $\mathrm{D}_{4 \mathrm{~h}}\left({ }^{1} \mathrm{~A}_{\mathrm{g}}\right)$ & -11077.60784 & 7.19 & 6.06 & 2.804 \\
\hline
\end{tabular}

Table 4. Optimized geometry and electronic properties calculation results for $\left(\mathrm{H}_{2} \mathrm{TPP}\right)_{3}$ trimers.

\begin{tabular}{lcccc}
\hline \multicolumn{1}{c}{ Type and symmetry of trimers } & $E_{\text {tot }}$ a.u. & $\begin{array}{c}E_{\mathrm{tot}}-E_{\mathrm{GS}}, \\
\mathrm{kcal} / \mathrm{mol}\end{array}$ & $\begin{array}{r}\left.2 E(\mathrm{ZnTPP})-E_{\mathrm{tot}}(\mathrm{ZnTPP})_{2}\right], \\
\mathrm{kcal} / \mathrm{mol}\end{array}$ & $\begin{array}{c}\text { HOMO-LUMO, } \\
\mathrm{eV}\end{array}$ \\
\hline "Straight staircase" with shifting towards $x ; y, C_{\mathrm{i}}\left({ }^{1} A_{\mathrm{g}}\right)$ & -5742.99225 & 0 & 7.79 & 2.727 \\
"Zig-zag" structure with shifting towards $x ; y$ or $-x ; y, C_{2,}\left({ }^{1} A\right)$ & -5742.99172 & 0.32 & 7.45 & 2.723 \\
"Back step staircase" with shifting towards $x ; y, \mathrm{C}_{\mathrm{s}}\left({ }^{1} A_{1}\right)$ & -5742.99128 & 0.60 & 7.19 & 2.614 \\
"Straight staircase" with shifting towards $\left.x, C_{2 \mathrm{~h}}{ }^{1} A_{\mathrm{g}}\right)$ & -5742.98988 & 1.48 & 6.32 & 2.679 \\
"Back step staircase" with shifting towards $x, C_{2 \mathrm{v}}\left({ }^{1} A_{1}\right)$ & -5742.98940 & 1.80 & 5.99 & 2.684 \\
"Zig-zag" structure with shifting towards $x$ or $\left.y, C_{1}{ }^{1} A\right)$ & -5742.98820 & 2.54 & 5.26 & 2.6485 \\
\hline
\end{tabular}




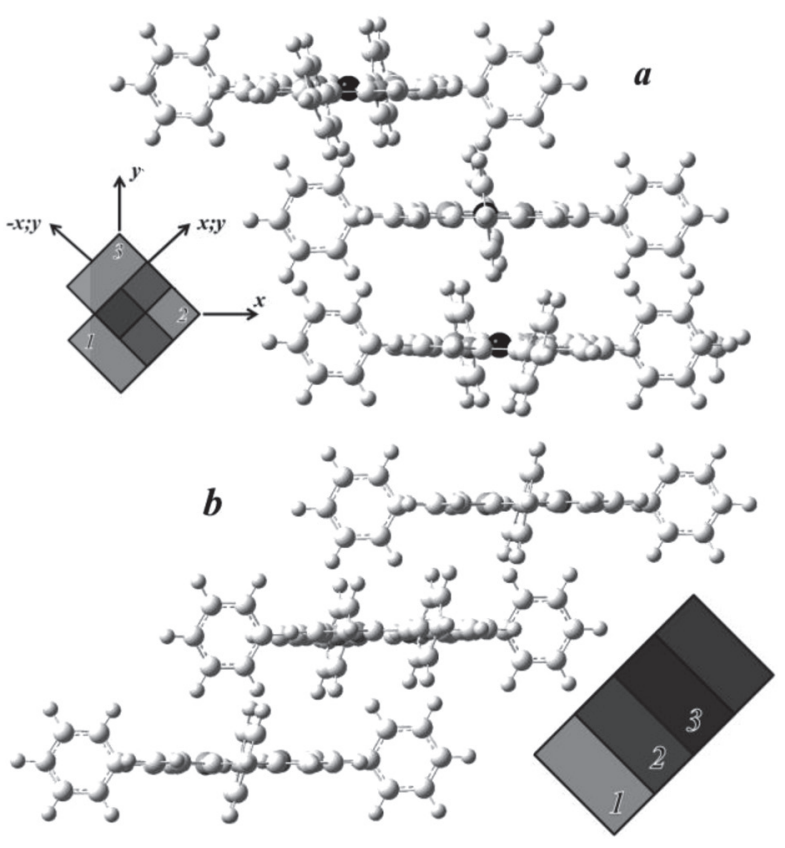

Figure. 3. Optimal geometry of trimers given by quantumchemical calculations: $a$ - "Zig-zag" structure for (ZnTPP), $b$ - "Straight stair" for $\left(\mathrm{H}_{2} \mathrm{TPP}\right)_{3}$.

per molecule increases with an increase of the number of molecules for both mentioned tetraphenylporphyrins. A relatively small difference of the formation energy between various $\mathrm{H}_{2}$ TPP trimers configurations makes these structures equivalent to form at room temperature.

Moreover, if the growth of structures occurs according to the "Straight stair" and/or "Back step stair" scenario, it is possible to observe the nanowires formed from them, growing perpendicular to the substrate or at the angle of $60^{\circ}$. The last option was observed in our previous work. ${ }^{[8]}$ It is technologically easy to grow all possible variants of structures, slightly changing the growth conditions.

In the case of a small gain of formation energy of trimers, a structure of obtained crystals depends on the interaction with the substrate energy, in the preparation of planar films from $\mathrm{H}_{2}$ TPP. If this energy it is tiny, the scenario of crystallization will depend on $E_{\text {form }}$, if not, the result will be determined by the properties of the substrate. ${ }^{[14]}$

It is possible to obtain nanowires growing in the plane of the substrate, ${ }^{[8]}$ if there is a partial adhesion to the substrate. Significant differences between the formation energy of the ZnTPP ground state and other possible complexes structures make "Zig-zag" structures most likely to formation. Other types of self-organization are prohibited using standard methods of films production.

\section{Conclusions}

An explanation of self-organization appearance in some materials from the tetraphenylporphyrin group were observed using quantum chemical calculations.
The optimal geometries of dimers and trimers, the total energy of the complexes, the energy of the ground state and the energy of dimer/trimer formation, the energy of the HOMO and LUMO levels for the components and molecular complexes were calculated. The difference in energy gain of the formation of various dimers/trimers geometry gave an explanation of self-organization features in different types of tetraphenylporphyrin.

There is a large energy gain of the ground state compared to single molecules in the formation of non-covalently bounded complexes of tetraphenylporphyrins (dimers and trimers).

The energy gain per molecule increases for both ZnTPP and $\mathrm{H}_{2}$ TPP with an increase of the number of molecules making the non-covalently bounded complex.

ZnTPP has a tendency to form solid-state planar structure by any technological methods because its trimer optimal geometry with the lowest $E_{\text {form }}$ is the "Zig-zag" structure, which does not allow crystallization into linear nanostructure (nanowire). A significant difference between the ground state with the minimum total energy and other minor states (of the order of $1.4 \mathrm{kcal} / \mathrm{mol}$ ) makes it difficult to control the structures growth process. The formation of nanowires is unlikely using standard obtaining methods. ${ }^{[6]}$

Contrariwise $\left(\mathrm{H}_{2} \mathrm{TPP}\right)_{3}$ has another ground state "Straight stair", and a tiny difference of formation energies $(0.35-0.45 \mathrm{kcal} / \mathrm{mol})$ between the ground state and other configurations. It allows to control the growth of threedimensional formations, obtaining structures of a given configuration, including nanorods and nanowires.

\section{References}

1. Zeng K., Lu Y., Tang W., Zhao S., Liu Q., Zhu W., Xie Y. Chem. Sci. 2019, 10, 2186-2192.

2. Verykios A., Papadakis M., Soultati A., Skoulikidou M.C., Papaioannou G., Gardelis S., Fakis M. ACS Omega 2018, 3, 10008-10018.

3. Elemans J.A., Van Hameren R., Nolte R.J., Rowan A.E. $A d v$. Mater. 2006, 18, 1251-1266.

4. de la Torre G., Bottari G., Torres T. Adv. Energy Mater. 2017, 7, 1601700.

5. Janghouri M., Adineh M. J. Photochem. Photobiol., A: Chemistry 2017, 341, 31-38.

6. Elistratova M.A., Zakharova I.B., Romanov N.M., Panevin V.Y., Kvyatkovskii O.E. Semicond. 2016, 50, 1191-1197.

7. Hill J.P., Xie Y., Akada M., Wakayama Y., Shrestha L.K., Ji Q., Ariga K. Langmuir 2013, 29, 7291-7299.

8. Lee S.J., Hupp J.T., Nguyen S.B.T. Am. J. Chem. Soc. 2008, 130, 9632-9633.

9. Elistratova M.A., Zakharova I.B., Li G.V., Dubrovin R.M., Sreseli O.M. Semicond. 2019, 53, 51-54.

10. Becke A.D. Chem J. Phys. 1993, 98, 5648-5652.

11. Becke A.D. Phys. Rev. A. 1988, 38, 3098-3100.

12. Lee C., Yang W., Parr R.G. Phys. Rev. B. 1988, 37, 785-789.

13. Frisch M.J., Trucks G.W., Schlegel H.B., et al. Computer code GAUSSIAN 03, revision B.05, Gaussian, Inc., Pittsburgh, PA, 2003.

14. Auwärter W., Weber-Bargioni A., Brink S., Riemann A., Schiffrin A., Ruben M., Barth J.V. Chem. Phys. Chem. 2007, $8,250-254$. 